\title{
27. SULFUR GEOCHEMISTRY AT SITES 680 AND 686 ON THE PERU MARGIN ${ }^{1}$
}

\author{
Jean-Remi Mossmann, ${ }^{2,4}$ Andrew C. Aplin, ${ }^{3}$ Charles D. Curtis, ${ }^{2,4}$ and Max L. Coleman ${ }^{3}$
}

\begin{abstract}
We have measured the concentrations of (1) pore-water sulfide and (2) solid-phase pyrite, iron monosulfide (= acid volatile sulfide), elemental sulfur, and extractable and nonextractable organic ("kerogen") sulfur in sediments from Ocean Drilling Program (ODP) Sites 680 and 686. Pore-water sulfide defines classic "bell-shaped" profiles. Maximum concentrations of 6 to $12 \mathrm{mM}$ occur where sulfate is exhausted, or is most depleted, at depths between 15 and 50 mbsf. Sulfide resulting from bacterial sulfate reduction reacts in three ways: (1) some is reoxidized to elemental sulfur in surface sediments; (2) some reacts with detrital iron minerals to form iron monosulfide and pyrite, primarily in the top meter or two of the sediment; and (3) some reacts with, and is incorporated into, kerogen. Incorporation of reduced sulfur into kerogen occurs over the top $15 \mathrm{~m}$ of the sediment at both Sites 680 and 686 , after the main phase of pyrite formation. Up to $45 \%$ of the total sedimentary sulfur is organically bound, and concentrations of $12 \mathrm{wt} \%$ sulfur are reached in the kerogen. These values are like those measured in lithologically similar, but more deeply buried, sediments from the Monterey Formation.
\end{abstract}

\section{INTRODUCTION}

Bacterially mediated reduction of sulfate is a process common to all anoxic marine sediments, Peru-Chile Margin shelf sediments being no exception (Cragg et al., this volume). Sulfide resulting from this process might react in one or more of three ways: it might react with detrital iron minerals to form iron monosulfide and pyrite; it might be mixed, or diffuse back to the sediment surface and be reoxidized to elemental sulfur or sulfate; or it might react with, and be incorporated into, sedimentary organic matter (kerogen).

In nearshore, rapidly accumulating muds, pyrite formation and sulfide oxidation appear to be the dominant reaction pathways (Kaplan et al., 1963; Berner, 1964; 1970; Jorgensen, 1977; 1988; Goldhaber and Kaplan, 1980; Chanton et al, 1987). A restricted set of data suggests that organically bound sulfur makes up only a few percent of total sedimentary sulfur in nearshore sediments, and that concentrations of sulfur in kerogen are low (Westrich, 1983; Berner and Westrich, 1985; François, 1987).

Gransch and Posthuma (1974) speculated that the incorporation of sulfur into kerogen is an early diagenetic process. Their proposal was based on the observation that most sulfur-rich crude oils are generated from iron-poor, biogenic source rocks, presumably from correspondingly sulfur-rich kerogens. In their model, a finite reservoir of bacterially produced, early diagenetic sulfide is partitioned between detrital iron minerals and sedimentary organic matter, so that iron-poor sediments end up with sulfur-rich organic matter.

Sediments accumulating on the Peru-Chile margin provide a useful test for these ideas. They contrast with nearshore sediments in their lower accumulation rate (Site 680: 30 $\mathrm{m} / \mathrm{m}$.y.; Site $686: 170 \mathrm{~m} / \mathrm{m}$.y.; nearshore sediments: more than $1000 \mathrm{~m} / \mathrm{m} . y . ;$ Suess, von Huene, et al., 1988) and their occurrence under an area of exceptionally high primary pro-

\footnotetext{
${ }^{1}$ Suess, E., von Huene, R., et al., 1990. Proc. ODP, Sci. Results, 112: College Station, TX (Ocean Drilling Program).

2 Dept. of Geology, Univ, of Sheffield, Sheffield S3 7HF, United Kingdom.

${ }^{3}$ BP Research International, Chertsey Road, Sunbury-on-Thames TW16 7LN, United Kingdom.

${ }^{4}$ Present address: Dept. of Geology, Univ. of Manchester, Manchester M13 9PL, United Kingdom.
}

ductivity. Compared to nearshore environments, the rate of supply of detrital iron on the Peru margin is relatively low, and the rate of supply of organic matter is relatively high. Furthermore, since the rate of sulfate reduction is related to the rate of supply of labile organic matter (Westrich, 1983), the balance of sulfate and iron reduction might also be expected to be different on the Peru margin, with sulfate reduction, and thus sulfide production, of relatively greater importance.

\section{SAMPLE SELECTION}

We chose Holes 680B and 686B for detailed studies. Both holes are located on the continental shelf but contain sediments that are physically and chemically distinct. Hole $680 \mathrm{~B}$ was drilled in $250 \mathrm{~m}$ of water within a lens-shaped accumulation of organic-rich upwelling sediments (Suess, von Huene, et al., 1988). We took samples from lithologic Units I and III (Fig. 1). Unit I (0-48 meters below sea floor [mbsf]) is made up of alternating beds of laminated and massive foraminiferbearing diatomaceous muds or oozes. It is organic-rich (total organic carbon $[\mathrm{TOC}]=3 \%$ to $10 \%$; Emeis and Morse, this volume) and accumulated at about $30 \mathrm{~m} / \mathrm{m}$.y. (Suess, von Huene, et al., 1988). Unit III is a gray, feldspathic mud, is relatively organic-lean (TOC $=1$ to $3 \%$; Emeis and Morse, this volume), and contains both massive and laminated sections. Below 80 mbsf, Unit III accumulated at about 100 $\mathrm{m} / \mathrm{m} . \mathrm{y}$. (Suess, von Huene, et al., 1988).

The composition of interstitial waters at Site 680 is strongly influenced by the presence of a hypersaline brine, which appears to originate below the cored section (Kastner et al., this volume). Of specific relevance here is the fact that brine is enriched in sulfate, and that sulfate is never wholly depleted from the interstitial water. Sulfate concentrations decrease from $25.3 \mathrm{mM}$ at $1.3 \mathrm{mbsf}$ to a minimum of $6 \mathrm{mM}$ at $48 \mathrm{mbsf}$, and then increase downcolumn to $37.9 \mathrm{mM}$ at $195.5 \mathrm{mbsf}$.

Hole 686B was drilled at a water depth of $450 \mathrm{~m}$ in the West Pisco Basin (Suess, von Huene, et al., 1988). We took samples from lithologic Units I, II, and III (Fig. 1). Units I and III (0-24.3 mbsf; 97.4-144.5 mbsf) comprise sandy, mainly laminated diatomaceous muds, while Unit II contains a higher proportion of bioturbated sediments. Compared with those at Site 680 , sediments at Site 686 are organic-lean and have accumulated rapidly (TOC $=1 \%$ to $3 \%$; , sedimentation rate $=$ $170 \mathrm{~m} / \mathrm{m} . y$.; Suess, von Huene, et al., 1988). Furthermore, 

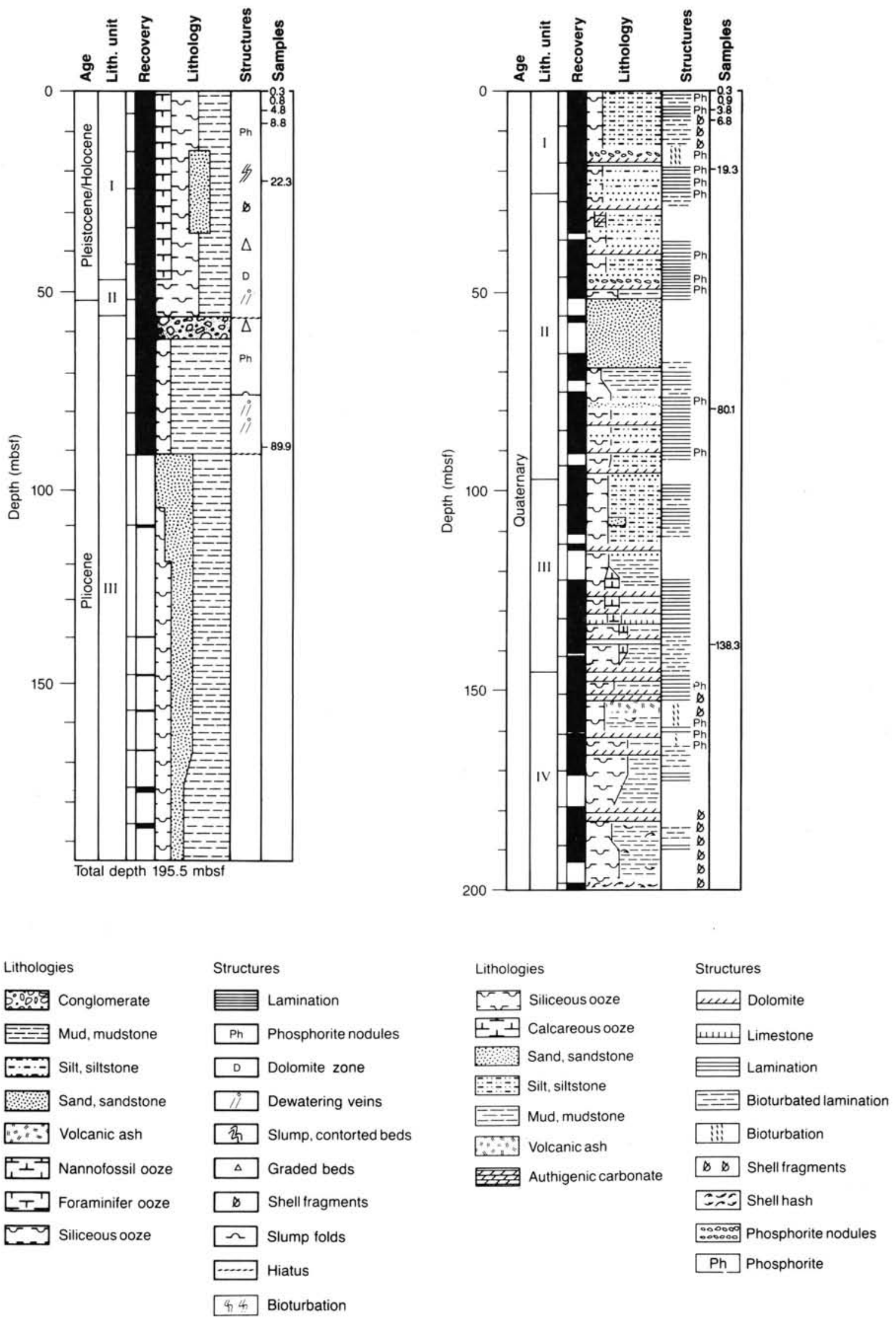

Figure 1. Lithostratigraphic columns of Holes $680 \mathrm{~B}$ and $686 \mathrm{~B}$. 
Table 1. Interstitial-water sulfide and sulfate.

\begin{tabular}{|c|c|c|c|}
\hline $\begin{array}{l}\text { Core, section, } \\
\text { interval }(\mathrm{cm})\end{array}$ & $\begin{array}{l}\text { Depth } \\
\text { (m) }\end{array}$ & $\begin{array}{l}\text { Sulfide } \\
(\mathrm{mM})\end{array}$ & $\begin{array}{l}\text { Sulfate } \\
(\mathrm{mM})\end{array}$ \\
\hline \multicolumn{4}{|l|}{ Site 680} \\
\hline $112-680 \mathrm{C}-1 \mathrm{H}-1,130-150$ & 1.3 & 2.0 & 25.3 \\
\hline $112-680 \mathrm{~B}-1 \mathrm{H}-2,145-150$ & 3.0 & 3.6 & 19.4 \\
\hline $112-680 \mathrm{C}-1 \mathrm{H}-3,145-150$ & 4.5 & 1.2 & 20.6 \\
\hline $112-680 \mathrm{C}-2 \mathrm{H}-3,140-150$ & 6.3 & 2.6 & 18.1 \\
\hline $112-680 \mathrm{C}-3 \mathrm{H}-2,145-150$ & 18.3 & 4.3 & 12.6 \\
\hline $112-680 \mathrm{~B}-3 \mathrm{H}-3,145-150$ & 19.5 & 5.6 & 11.0 \\
\hline $112-680 \mathrm{~B}-6 \mathrm{H}-3,145-150$ & 47.5 & 4.5 & 6.0 \\
\hline 112-680B In-Situ No. I & 62.5 & n.m. & 10.1 \\
\hline $112-680 \mathrm{~B}-9 \mathrm{H}-1,001-010$ & 72.0 & 0.1 & n.m. \\
\hline $112-680 \mathrm{~B}-9 \mathrm{H}-4,140-150$ & 77.9 & n.m. & 12.3 \\
\hline $112-680 \mathrm{~A}-10 \mathrm{H}-1,001-010$ & 84.3 & 0.0 & n.m. \\
\hline 112-680B In-Situ No. 2 & 195.5 & n.m. & 37.9 \\
\hline \multicolumn{4}{|l|}{ Site 686} \\
\hline $112-686 \mathrm{~B}-1 \mathrm{H}-3,145-150$ & 4.5 & 3.0 & 19.1 \\
\hline $112-686 \mathrm{~B}-2 \mathrm{H}-1,145-150$ & 13.0 & 11.8 & 1.8 \\
\hline $112-686 \mathrm{~B}-3 \mathrm{H}-3,145-150$ & 22.5 & n.m. & 0 \\
\hline $112-686 \mathrm{~B}-5 \mathrm{H}-3,145-150$ & 41.5 & 1.1 & 0 \\
\hline $112-686 \mathrm{~B}-6 \mathrm{X}-3,145-150$ & 49.5 & n.m. & 0 \\
\hline $112-686 \mathrm{~B}-9 \mathrm{X}-3,145-150$ & 84.0 & n.m. & 0 \\
\hline $112-686 \mathrm{~B}-12 \mathrm{X}-3,145-150$ & 106.5 & n.m. & 0 \\
\hline 112-686A In-Situ No. I & 110.7 & n.m. & 0 \\
\hline $112-686 \mathrm{~B}-15 \mathrm{X}-5,140-150$ & 139.5 & n.m. & 0 \\
\hline $112-686 \mathrm{~B}-16 \mathrm{X}-4,140-150$ & 166.4 & n.m. & 0 \\
\hline 112-686A In-Situ No. 2 & 186.7 & n.m. & 0 \\
\hline
\end{tabular}

Note: n.m. $=$ not measured

(sulfate data from Suess, von Huene, et al., 1988)

interstitial waters in Hole 686B are less affected by the saline brine than those in Hole $680 \mathrm{~B}$; sulfate has been rapidly depleted in Hole 686B and was exhausted at 14 mbsf (Kastner et al., this volume).

Samples analyzed were aliquots of those supplied to the UK consortium. All the samples, except for those from 0.8 and 138.3 mbsf in Hole 686B, were taken from laminated core sections. Sampling frequency decreased exponentially down the column, paralleling the expected decline in the intensity of microbial diagenesis.

\section{METHODS}

\section{Dissolved Sulfide}

Dissolved sulfide was fixed on board the JOIDES Resolution by squeezing interstitial waters into a fixed volume of 0.1 $\mathrm{N}$ silver nitrate $\left(\mathrm{AgNO}_{3}\right)$. Samples were stored in sealed vials at $4^{\circ} \mathrm{C}$ for later analysis.
Onshore, the mixture of interstitial water and $\mathrm{AgNO}_{3}$ was separated from the silver sulfide $\left(\mathrm{Ag}_{2} \mathrm{~S}\right)$ and weighed. The $\mathrm{Ag}_{2} \mathrm{~S}$ was purified by washing twice with distilled water, once with concentrated ammonia solution, and again with distilled water. The $\mathrm{Ag}_{2} \mathrm{~S}$ was freeze-dried and weighed. Measurement of the volume of interstitial water, plus $\mathrm{AgNO}_{3}$, enabled us to calculate the volume of interstitial water and thus the true concentrations of dissolved sulfide (Table 1).

\section{Solid Samples}

Large volume samples were received in sealed plastic bags several weeks after coring. Subsamples were immediately sealed into plastic bags and stored deep-frozen in nitrogenfilled anaerobic jars.

After thawing and homogenization in a nitrogen glove bag, each sample was divided into two aliquots. One was freeze-dried and used for the analysis of (1) major oxides by X-ray fluorescence (Table 2), (2) total carbon and sulfur using a LECO C-S analyzer, and (3) carbonate carbon by infra-red detection of the carbon dioxide evolved by reaction with $60 \%$ hydrochloric acid. The second aliquot was used for the analysis of sulfur species. Acid volatile sulfide (AVS), extractable organic sulfur, elemental sulfur, pyrite sulfur, and nonextractable organic sulfur were sequentially removed and precipitated as $\mathrm{Ag}_{2} \mathrm{~S}$ or barium sulfate $\left(\mathrm{BaSO}_{4}\right)$, according to the procedures outlined in Fig. 2 (see also Chanton and Martens, 1985; Canfield et al., 1986). Amounts of extracted sulfur were calculated in two ways: (1) directly, by weighing $\mathrm{Ag}_{2} \mathrm{~S}$ and $\mathrm{BaSO}_{4}$ precipitates, and (2) indirectly, by determining the weight of sulfur in the sediments before and after each extraction stage. The two results were then averaged. The initial sulfur content of the sediments, and the sum of the separated species, agree to within $10 \%$ (Table 3 ).

Our experience with other modern sediments suggests that unstable, reduced iron phases like AVS tend to be oxidized during the freeze-drying procedure. We therefore extracted AVS directly from wet sediment. Minerals other than AVS are dissolved by this procedure, so that the initial weight of dry sediment must be calculated by combining the weight of the residue of the AVS extraction with a chemical analysis of the leachate. We analyzed the leachate for iron, magnesium, calcium, phosphorous, silicon, and aluminum and assigned the ions to dissolved apatite, carbonate, gibbsite, and silica. The dissolved minerals were added back to the residue of the AVS extraction to give the initial weight of sediment. The accuracy of the technique was verified by analyzing other Holocene sediments in the same way and comparing the

Table 2. Bulk geochemical data.

\begin{tabular}{crrrrrrrr}
\hline $\begin{array}{c}\text { Core, section, } \\
\text { interval (cm) }\end{array}$ & $\begin{array}{c}\text { Depth } \\
\text { (mbsf) }\end{array}$ & $\begin{array}{c}\mathrm{Al} \\
(\%)\end{array}$ & $\begin{array}{c}\mathrm{Fe}^{\mathrm{a}} \\
(\%)\end{array}$ & $\begin{array}{c}\text { Soluble Fe } \\
(\%)\end{array}$ & $\begin{array}{c}\mathrm{S} \\
(\%)\end{array}$ & $\begin{array}{c}\text { TOC } \\
(\%)\end{array}$ & DOP $_{\mathrm{T}}^{\mathrm{b}}$ & DOP $_{\mathrm{R}} \mathrm{c}^{\mathrm{c}}$ \\
\hline $112-680 \mathrm{~B}-1 \mathrm{H}-1,17-39$ & 0.3 & 6.6 & 1.8 & 0.44 & 1.2 & 9.0 & 0.41 & 0.63 \\
$-1 \mathrm{H}-1,70-82$ & 0.8 & 6.4 & 1.8 & 0.36 & 1.2 & 7.3 & 0.36 & 0.64 \\
$-1 \mathrm{H}-4,26-34$ & 4.8 & 6.3 & 1.9 & 0.40 & 1.5 & 5.4 & 0.46 & 0.69 \\
$-2 \mathrm{H}-3,29-37$ & 8.8 & 6.7 & 2.2 & 0.52 & 1.8 & 5.2 & 0.38 & 0.64 \\
$-3 \mathrm{H}-5,129-139$ & 22.3 & 5.0 & 1.8 & 0.38 & 2.0 & 7.0 & 0.56 & 0.74 \\
$-10 \mathrm{H}-6,88-100$ & 89.9 & 7.9 & 3.2 & 0.58 & 2.2 & 1.5 & 0.63 & 0.78 \\
112-686B-1H-1, 17-39 & 0.3 & 8.0 & 2.5 & 0.53 & 1.2 & 2.1 & 0.38 & 0.65 \\
$-1 \mathrm{H}-1,87-96$ & 0.9 & 7.8 & 2.7 & 0.52 & 1.3 & 1.5 & 0.38 & 0.67 \\
$-1 \mathrm{H}-3,79-81$ & 3.8 & 6.7 & 2.2 & 0.43 & 1.4 & 2.8 & 0.47 & 0.71 \\
$-1 \mathrm{H}-5,80-90$ & 6.8 & 8.4 & 2.5 & 0.41 & 1.0 & 1.2 & 0.32 & 0.67 \\
$-3 \mathrm{H}-2,33-45$ & 19.8 & 7.4 & 2.7 & 0.30 & 1.3 & 1.4 & 0.35 & 0.76 \\
$-9 \mathrm{X}-5,30-44$ & 80.1 & 6.2 & 2.2 & 0.53 & 1.3 & 2.5 & 0.37 & 0.61 \\
$-15 \mathrm{X}-5,32-42$ & 138.3 & 5.9 & 2.1 & 0.22 & 1.3 & 3.9 & 0.39 & 0.79 \\
\hline
\end{tabular}

a Total iron.

${ }^{b} \mathrm{DOP}_{\mathrm{T}}=$ Pyritic iron/Total Fe.

${ }^{c}$ DOP $_{\mathrm{R}}=$ Pyritic iron/(Pyritic iron $+6 \mathrm{~N} \mathrm{HCl}$ soluble iron). 
J. R. MOSSMANN, A. C. APLIN, C. D. CURTIS, M. L. COLEMAN

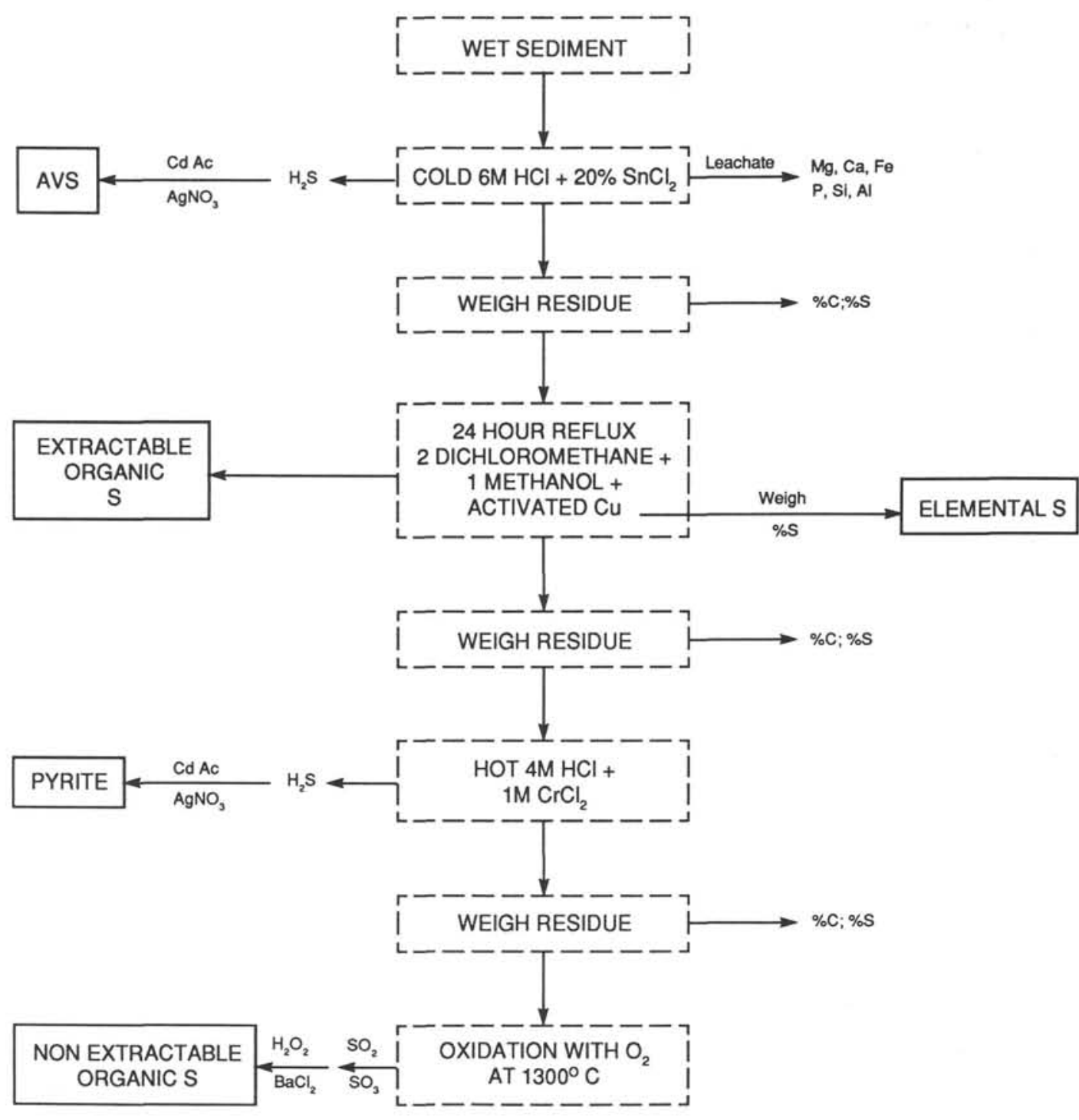

Figure 2. Analytical procedures. See text for further details.

Table 3. Partition of solid-phase sulfur species.

\begin{tabular}{crrrrrrr}
\hline & & \multicolumn{6}{c}{ Sulfur species (mg/g) } \\
\cline { 5 - 8 } $\begin{array}{c}\text { Core, section, } \\
\text { interval (cm) }\end{array}$ & $\begin{array}{c}\text { Depth } \\
(\mathrm{m})\end{array}$ & Total & Pyrite & Elemental & $\begin{array}{c}\text { Acid } \\
\text { volatile }\end{array}$ & $\begin{array}{c}\text { Extractable } \\
\text { organic }\end{array}$ & $\begin{array}{c}\text { Nonextractable } \\
\text { organic }\end{array}$ \\
\hline $112-680 \mathrm{~B}-1 \mathrm{H}-1,17-39$ & 0.3 & 11.5 & 8.5 & 0.78 & 0.03 & 0.08 & 2.42 \\
$-1 \mathrm{H}-1,70-82$ & 0.8 & 12.4 & 7.1 & 0.90 & 0.15 & 0.10 & 2.36 \\
$-1 \mathrm{H}-4,26-34$ & 4.8 & 15.1 & 9.9 & 0.43 & 0.22 & 0.10 & 5.42 \\
$-2 \mathrm{H}-3,29-37$ & 8.8 & 18.3 & 9.8 & 0.40 & 0.41 & 0.18 & 5.80 \\
$-3 \mathrm{H}-5,129-189$ & 22.3 & 19.8 & 11.2 & 0.43 & 0.42 & 0.04 & 10.39 \\
$-10 \mathrm{H}-6,88-100$ & 89.9 & 22.2 & 23.3 & 0.03 & 0.32 & 0.07 & 1.89 \\
& & & & & & 0.03 & 1.30 \\
$112-686 \mathrm{~B}-1 \mathrm{H}-1,17-39$ & 0.3 & 12.3 & 11.0 & 0.12 & 0.04 & 0.05 & 0.80 \\
$-1 \mathrm{H}-1,87-96$ & 0.9 & 12.6 & 11.8 & 0.14 & 0.06 & 0.01 & 3.10 \\
$-1 \mathrm{H}-3,79-81$ & 3.8 & 13.8 & 11.6 & 0.11 & 0.08 & 0.05 & 1.65 \\
$-1 \mathrm{H}-5,80-90$ & 6.8 & 10.3 & 9.1 & 0.07 & 0.16 & 0.06 & 1.55 \\
$-3 \mathrm{H}-2,33-45$ & 19.8 & 13.3 & 10.6 & 0.01 & 0.32 & 0.10 & 2.35 \\
$-9 \mathrm{X}-5,30-44$ & 80.1 & 12.7 & 9.2 & 0.11 & 0.15 & 0.06 & 2.50 \\
$-15 \mathrm{X}-5,32-42$ & 138.3 & 12.5 & 9.5 & n.d. & 0.04 & 0.20 & \\
\hline
\end{tabular}

n.d. $=$ not detected. 


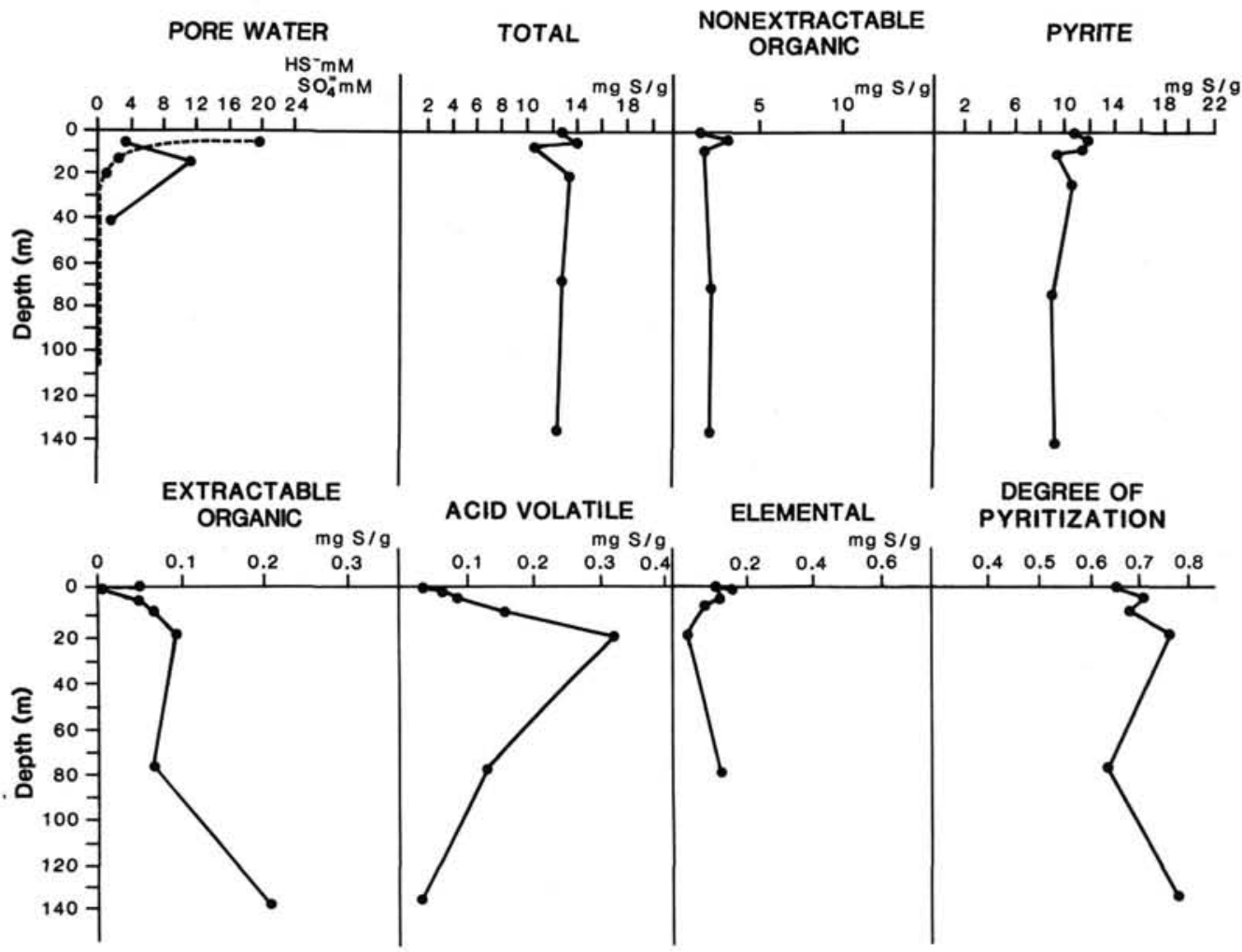

Figure 3. Vertical profiles of pore-water sulfate and sulfide, solid-phase sulfur species, and degree of pyritization in sediments from Site 686.

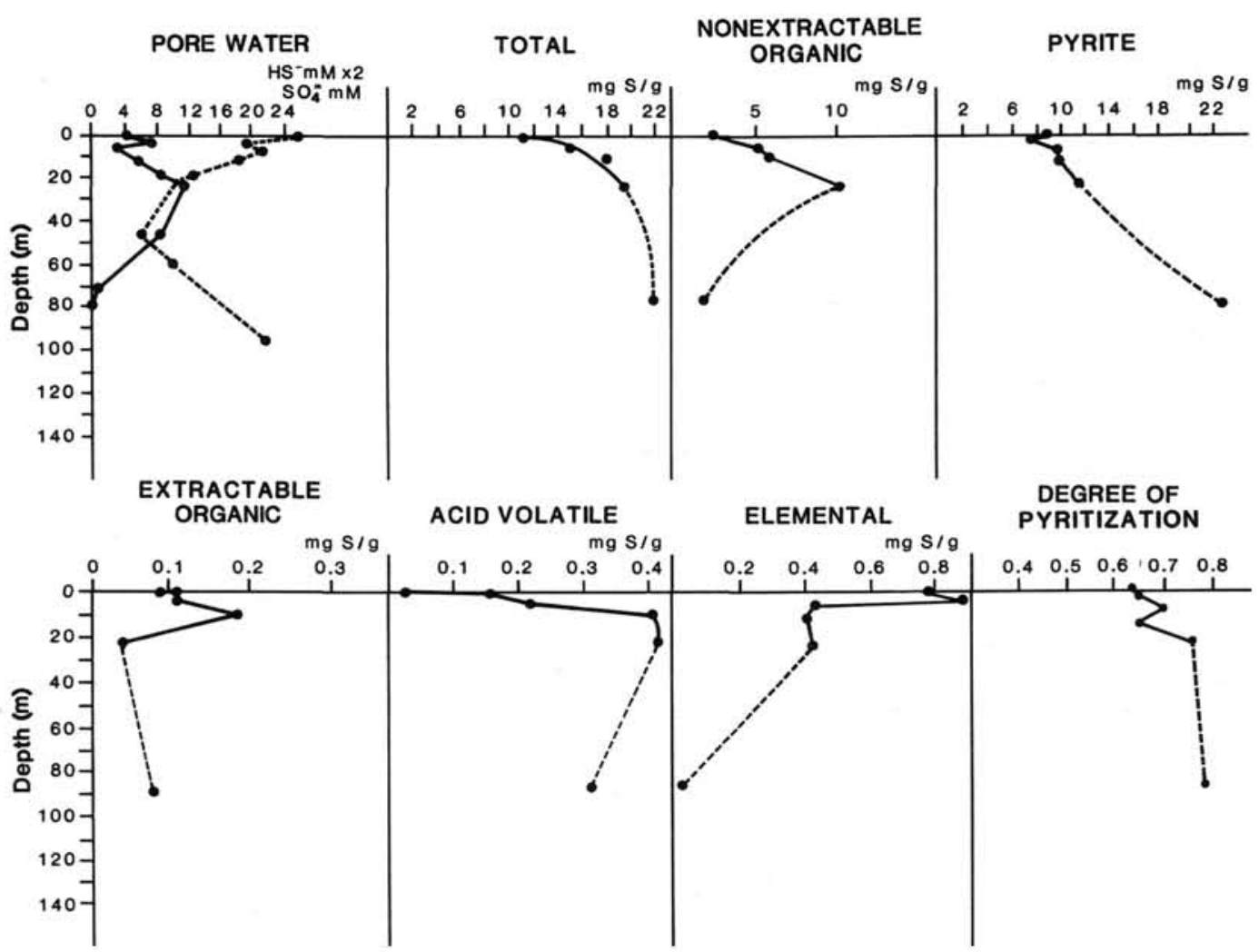

Figure 4. Vertical profiles of pore-water sulfate and sulfide, solid-phase sulfur species, and degree of pyritization in sediments from Site 680 . Dashed line indicates that the deepest sample is from a lithologically different unit and is strictly not comparable with the other samples. 
results with those determined by air-drying. Results from the two procedures agreed to within $3 \%$.

\section{DISSOLVED SULFUR SPECIES}

Interstitial sulfate and sulfide (Table 1) were measured on $\mathrm{A}, \mathrm{B}$ and $\mathrm{C}$ cores, and the results combined into single profiles (Figs. 3 and 4).

\section{Sulfate}

At Site 686 , sulfate concentrations decline from $20 \mathrm{mM}$ in surface sediments to $0 \mathrm{mM}$ at about $14 \mathrm{mbsf}$ (Fig. 3). This is the classic diffusion/reaction profile observed in most anoxic marine sediments, although the depth at which the sulfate becomes exhausted is greater than that normally encountered in nearshore, anoxic sediments (e.g., Goldhaber et al. 1977; Chanton et al., 1987). In contrast, sulfate is never fully depleted at Site 680 (Fig. 4). A minimum value of about $6 \mathrm{mM}$ occurs at $47 \mathrm{mbsf}$, below which concentrations increase to $38 \mathrm{mM}$-higher than seawater values-at a depth of 195 mbsf. The chemistry of sulfate in interstitial waters at Sites 680 and 686 may thus be distinguished in two ways; (1) sulfate is more quickly depleted in Site 686, and (2) sulfate is replenished in Site 680 from a deep, high-sulfate saline brine (Kastner et al., this volume).

\section{Sulfide}

Despite small data sets, pore-water sulfide concentrations at both sites appear to define the classic bell-shaped profiles observed in other anoxic marine sediments (e.g., Goldhaber et al., 1977; Goldhaber and Kaplan, 1980; Figs. 3 and 4). Maximum sulfide concentrations occur near the point where sulfate is fully depleted or is at a minimum. Thus, a maximum sulfide concentration of $11.8 \mathrm{mM}$ occurs at 13 mbsf in Site 686 sediments, compared with $5.6 \mathrm{mM}$ at $19.5 \mathrm{mbsf}$ in Site 680 sediments. Such values are somewhat higher than those measured in nearshore, terrigenous sediments (e.g., Goldhaber and Kaplan, 1980; Chanton et al., 1987; François, 1987) and occur much deeper in the sediment column.

We think that the deep dissolved maxima of sulfide, and deep minima of sulfate (or depth of exhaustion), result from the specific depositional environment of the Peru-Chile shelf. First, oxygen-depleted bottom waters inhibit bioturbation and promote the preservation of labile organic matter. Second, relatively low rates of sedimentation allow sulfate to diffuse deep into the sediment pile, as long as sulfate gradients can be maintained by continued sulfate reduction. This is ensured by the high primary productivity and associated large flux of labile organic matter to the sediment surface.

At Site 680 , dissolved sulfide concentrations decrease to zero below 60 mbsf (Fig. 4). Because sulfide-consuming reactions, for example, reaction with iron minerals, are likely to be slow in such deeply buried sediments, this implies that rates of sulfide production (and thus of sulfate reduction) must also be slow in the deep parts of the saline brine.

\section{SOLID-PHASE SULFUR}

\section{Inorganic Sulfur Species}

Concentrations of pyrite, AVS, and elemental sulfur are listed in Table 3 and are plotted as depth profiles in Figures 3 and 4. Pyrite makes up more than $90 \%$ of the reduced inorganic sulfur, and (except for a single sample from Site 680) occurs in broadly similar amounts in sediments from both sites: pyritic sulfur $=9.3 \mathrm{mgg}^{-1} \pm 1.6$ in Site 680 sediments, and $10.4 \mathrm{mgg}^{-1} \pm 1.1$ in Site 686 sediments. However, while the abundance of pyrite is essentially constant at Site 686 , this abundance increases down Unit I at Site 680 and is much greater in the single sample from Unit III.
Pyrite formation can be limited by the availability of any one of three key reactants: labile organic matter, pore-water sulfate, and detrital iron minerals (Berner, 1970). Organic matter is unlikely to limit pyrite formation at either Site 680 or Site 686. Cragg et al. (this volume) have demonstrated that the organic matter even deep within Site 681 sediments can be utilized by sulfate-reducing bacteria, and this same type of organic matter occurs throughout sediments from Sites 680 and 686 (Patience et al., this volume).

Sulfate availability is also unlikely to be a significant limitation on pyrite formation. The case is clear at Site $\mathbf{6 8 0}$, where sulfate is never fully depleted, but is less certain at Site 686, where sulfate is exhausted at about 15 mbsf (Fig. 3). However, the abundance of pyrite does not increase significantly through the sulfate-reduction zone at Site 686, implying that most pyrite formed in surface sediments.

We conclude that at both sites the abundance of pyrite is effectively limited by the availability of reactive iron. We stress "reactive" because, despite the highly sulfidic porewater at both sites, only $47 \% \pm 11$ of the total iron at Site 680 , and $38 \% \pm 5$ of the total iron at Site 686 , occurs as pyrite (Table 2 ). The conditions and rates of reaction between specific iron minerals and dissolved sulfide are not well known, but it is useful to envisage a scale of reactivity in which some minerals (like oxyhydroxides) react almost instantaneously, while others (like iron-bearing clays) may be essentially unreactive under early diagenetic conditions. Other minerals, like magnetite, would be expected to have intermediate reactivities and to be slowly converted to pyrite if concentrations of pore-water sulfide were maintained at high levels for long periods. Berner (1970) proposed that iron minerals soluble in $6 \mathrm{~N}$ hydrochloric acid ( $\mathrm{HCl})$ might be those that could be converted to pyrite under extreme, highly sulfidic, early diagenetic conditions, and measurements on ancient mudrocks tend to support this hypothesis (Raiswell et al., 1988). Berner (1970) proposed the parameter "Degree of Pyritization"' (DOP) as a measure of the proportion of potentially reactive iron that had been converted to pyrite:

$$
\mathrm{DOP}=\frac{\text { Pyritic Fe }}{\text { Pyritic } \mathrm{Fe}+6 \mathrm{~N} \mathrm{HCl} \text { soluble } \mathrm{Fe}} .
$$

Values of DOP in sediments from both Sites 680 and 686 are between 0.60 and 0.79 and show no clear trend with depth (Figs. 3 and 4). The data suggest that although iron is still potentially reactive in the deepest parts of the sediments at both sites, most pyrite formed within a meter or two of the sediment surface. This implies that two distinct populations of iron minerals occur: one that reacts very rapidly, and a second that reacts very slowly, or not at all. Emeis and Morse's (this volume) work on Site 680 sediments supports this contention.

They calculated DOP as

$$
\mathrm{DOP}=\frac{\text { Pyritic } \mathrm{Fe}}{\text { Pyritic } \mathrm{Fe}+1 \mathrm{~N} \mathrm{HCl} \text { soluble Fe }}
$$

and found constant values between 0.85 and 0.90 in all samples, including surface sediments.

Clearly, most iron sulfide formed in surface sediments. However, increasing abundances of AVS over the top $20 \mathrm{~m}$ of sediments at both sites testify to the continued, slow reaction between sulfide and detrital iron minerals (Figs. 3 and 4). AVS is generally considered as the first, metastable, product of the reaction sequence that converts dissolved sulfide and iron 
ORGANIC S/C

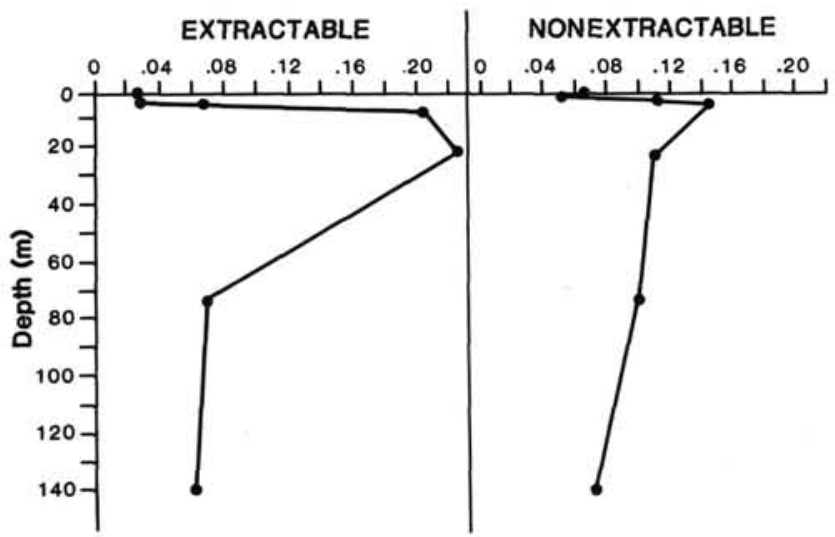

Figure 5. Vertical profiles of the S/C ratio of extractable and nonextractable organic matter in sediments from Hole 686B.

minerals to pyrite (Berner, 1964; Rickard, 1975). Its abundance is therefore a function of both its rate of formation and its rate of transformation. Low concentrations of AVS in surface sediments might imply its rapid transformation to pyrite, or that it never formed at all. Higher concentrations in deeper sediments indicate the continued formation of AVS; the striking similarity between the concentration profiles of AVS and of dissolved sulfide suggest that continued reaction between iron minerals and sulfide is a direct result of the enhanced concentrations of pore-water sulfide: more refractory iron minerals reacting in more sulfidic waters.

The abundance of elemental sulfur is greatest in surface sediments at both sites and declines steadily down the column (Figs. 3 and 4). Concentrations are higher in Site 680 ; a maximum value of $0.9 \mathrm{mgg}^{-1}$, or $7 \%$ of the total sulfur, compared with $0.1 \mathrm{mgg}^{-1}$ in surface sediments at Site 686 . Apparently, elemental sulfur is being formed near the sediment/water interface and is being consumed as the sediment is buried. Because of its vertical distribution and its intermediate valence state, elemental sulfur may have formed as a result of either (1) bacterial sulfate reduction, or (2) bacterial or chemical sulfide oxidation-all of these processes would be most intense in surface sediments. However, note that "estopa" (Spanish for uncleaned wool or flax), or filamentous sulfide-oxidizing bacteria, have been

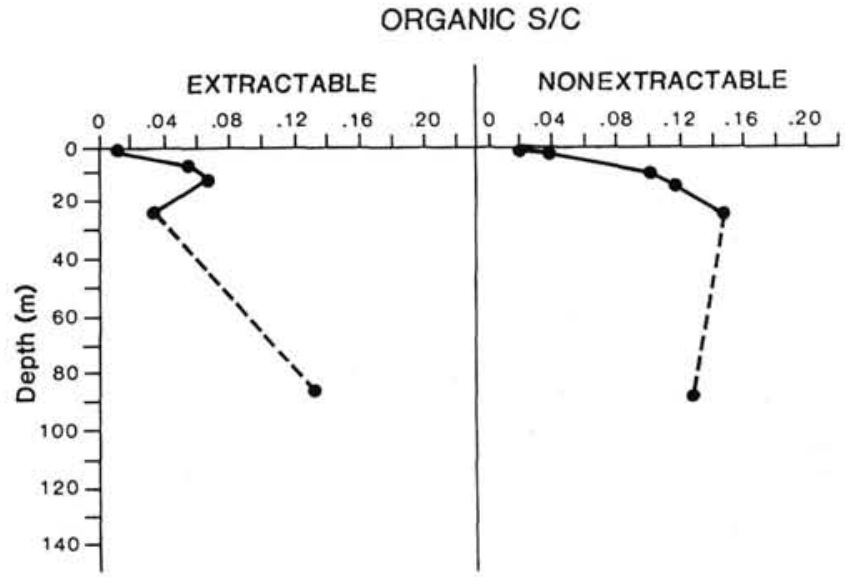

Figure 6. Vertical profiles of the S/C ratio of extractable and nonextractable organic matter in sediments from Hole 680B. Dashed line indicates that the deepest sample is from a lithologically different unit and is strictly not comparable with the other samples.

isolated from surface sediments elsewhere on the Peru-Chile margin (Gallardo, 1977).

\section{Organic Sulfur Species}

Marine algal matter, which is essentially the only type of organic matter supplied to Sites 680 and 686 (Patience et al., this volume), has a sulfur/carbon $(\mathrm{S} / \mathrm{C})$ weight ratio of less than 0.02 (François, 1987). The S/C ratio of organic matter in all the sediments from Sites 680 and 686 is greater than 0.02 , indicating diagenetic enrichment of sulfur. Depth profiles of the $\mathrm{S} / \mathrm{C}$ ratios of both nonextractable organic matter (kerogen), and solvent-extractable organic matter are shown in Figs. 5 and 6 . At both Sites 680 and 686 , a steady uptake of sulfur into kerogen (which makes up more than $90 \%$ of the total organic matter; Table 4) occurs over the upper part of the sediment column, with $\mathrm{S} / \mathrm{C}$ ratios increasing from about 0.04 in surface sediments to about 0.15 at 5 to $15 \mathrm{~m}$. The data show that the uptake of sulfur into sedimentary organic matter commences in the top meter or two of the sediment column but continues after the major phase of pyrite formation. This implies that organic matter reacts with reduced sulfur more slowly than many, but by no means all, of the sedimented iron minerals. Once the more reactive iron minerals have been converted to pyrite, then reduced sulfur reacts with, and is incorporated into, kerogen.

Table 4. Organic carbon data.

\begin{tabular}{crccc}
\hline $\begin{array}{c}\text { Core, section, } \\
\text { interval }(\mathrm{cm})\end{array}$ & $\begin{array}{c}\text { Depth } \\
(\mathrm{mbsf})\end{array}$ & $\begin{array}{c}\text { TOC } \\
(\mathrm{mg} / \mathrm{g})\end{array}$ & $\begin{array}{c}\text { Extractable carbon } \\
(\mathrm{mg} / \mathrm{g})\end{array}$ & $\begin{array}{c}\text { Nonextractable carbon } \\
(\mathrm{mg} / \mathrm{g})\end{array}$ \\
\hline $112-680 \mathrm{~B}-1 \mathrm{H}-1,17-39$ & 0.3 & 89.7 & 6.9 & 82.8 \\
$-1 \mathrm{H}-1,70-82$ & 0.8 & 73.4 & 7.2 & 66.2 \\
$-1 \mathrm{H}-4,26-34$ & 4.8 & 53.8 & 2.4 & 51.4 \\
$-2 \mathrm{H}-3,29-37$ & 8.8 & 51.6 & 3.1 & 48.5 \\
$-3 \mathrm{H}-5,129-189$ & 22.3 & 70.1 & 1.2 & 68.9 \\
$-10 \mathrm{H}-6,88-100$ & 89.9 & 15.4 & 0.5 & 14.9 \\
$112-686 \mathrm{~B}-1 \mathrm{H}-1,17-39$ & 0.3 & 21.0 & 1.7 & 19.3 \\
$-1 \mathrm{H}-1,87-96$ & 0.9 & 14.9 & 0.3 & 14.6 \\
$-1 \mathrm{H}-3,79-81$ & 3.8 & 28.2 & 0.8 & 11.3 \\
$-1 \mathrm{H}-5,80-90$ & 6.8 & 11.6 & 0.3 & 13.4 \\
$-3 \mathrm{H}-2,33-45$ & 19.8 & 13.8 & 0.4 & 23.7 \\
$-9 \mathrm{X}-5,30-44$ & 80.1 & 24.6 & 0.9 & 35.5 \\
$-15 \mathrm{X}-5,32-42$ & 138.3 & 39.0 & 3.5 & \\
\hline
\end{tabular}

Note: Solvent used for extraction was a 2:1 mixture of dichloromethane and methanol. 


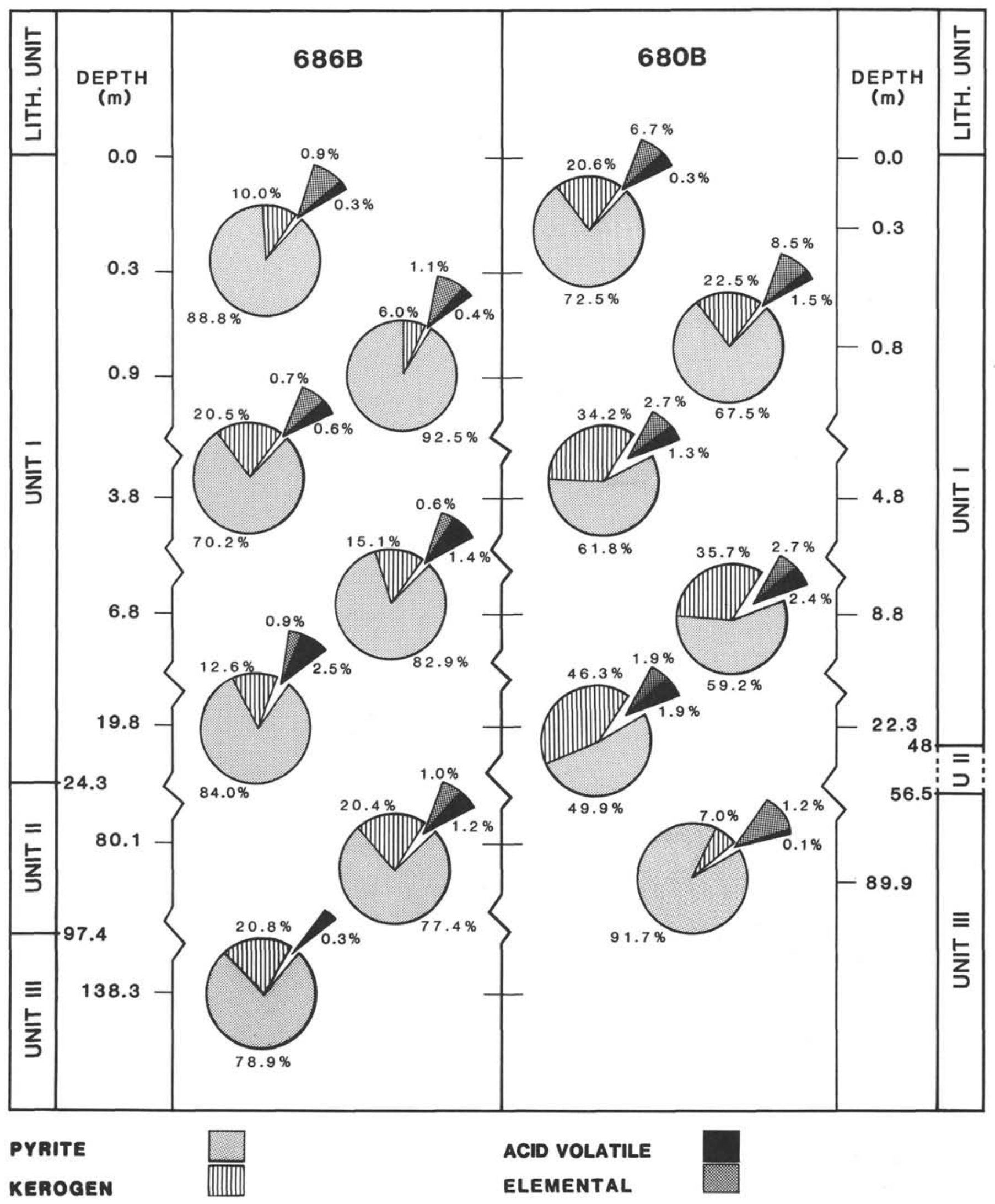

Figure 7. Partition of sedimentary sulfur in sediments from Holes $680 \mathrm{~B}$ and $686 \mathrm{~B}$. 
One might predict from the last statement that the concentration of sulfur in kerogen would be lower in sediments in which reactive iron is accumulating rapidly. But although iron is accumulating about six times faster in Site 686 sediments than in Site 680 sediments, the maximum sulfur contents of the kerogen are similar at both sites. This suggests that at both sites the accumulation rate of highly reactive iron has been sufficiently slow to allow its complete conversion to pyrite. Continued reduction of sulfate, below the main zone of pyrite formation, provides sufficient reduced sulfur to fuel substantial uptake into the kerogen structure. It is notable, and important, that the maximum sulfur content of the organic matter in sediments from Sites 680 and 686 is like that measured in more deeply buried, but lithologically similar, sediments from the Monterey Formation in California (Orr, 1986). The implication is that early diagenetic reactions exert a major control on the ultimate sulfur content of kerogen (and thus of crude oil), confirming Gransch and Posthuma's (1974) suggestion.

The sulfur content of kerogen peaks in the pore-water sulfide maximum and declines deeper in the sediment column at both sites (Figs. 3-6). Lower sulfur contents in deeper sediments may reflect different conditions of very early diagenesis, when most of the sulfur was incorporated into the kerogen. This hypothesis is certainly tenable for Site 680 , since the deeper, sulfur-depleted sample was taken from a lithologically different sedimentary unit. It is, however, less likely for the more lithologically uniform sediments from Site 686. Furthermore, the sulfur content of extractable organic matter in Site 686 sediments also declines dramatically, below the pore-water sulfide maximum. In contrast, the sulfur content of extractable organic matter in Site 680 sediments increases.

It is possible that the different behavior of organic sulfur deep in Sites 680 and 686 is related to the influx of saline brine to Site 680 . In the absence of sulfate, methanogenesis is the dominant microbial process in deep Site 686 sediments, as revealed by the high concentrations of pore-water methane (Kvenvolden et al., this volume). Methanogens derive energy by splitting oxygen-rich organic compounds, which has the effect of reducing the oxygen/carbon ratio of the bulk organic matter. The declining sulfur contents of kerogen, and especially of extractable organic matter, suggests that other fermentative bacteria may be able to use sulfur-rich organic compounds in a similar way as the methanogens use oxygenrich compounds. At Site 680 , the presence of sulfate in deep sediments may inhibit methanogenesis; pore-water methane concentrations are low (Kvenvolden et al., this volume). Increasing $\mathrm{S} / \mathrm{C}$ ratios in extractable organic matter below the pore-water sulfide maximum at Site 680 , and a less dramatic decrease in the $\mathrm{S} / \mathrm{C}$ ratio of kerogen, may indicate continuing reaction between reduced sulfur and kerogen in the saline brine.

\section{Partition of Sulfur}

The partition of sulfur between organic and inorganic phases is controlled by the relative proportions of pyritic sulfur and kerogen-bound sulfur, since these two phases make up more than $95 \%$ of the total sedimentary sulfur (Fig. 7). The difference between the sites is that pyrite makes up $80 \%$ to $90 \%$ of the total sulfur in Site 686 sediments, but only $50 \%$ to $70 \%$ in Site 680 sediments. In both cases, the proportion of pyritic sulfur is low in comparison with rapidly deposited, nearshore muds (Westrich, 1983; Berner and Westrich, 1985; François, 1987). The difference between the two sites partly reflects the somewhat greater iron contents of Site 686 sediments, as at both sites a similar proportion of total iron has been converted to pyrite. However, the main control of the partition of sulfur is simply the differing organic contents of the sediments at each site. The sulfur contents of organic matter are similar and are high at each site, so that the proportion of organically bound sulfur is correspondingly high in Site 680 sediments.

Within the sample suite from a single site, the partition of sulfur between organic and inorganic phases changes in response to the increasing sulfur content of kerogen down into the sediment column (Fig. 7). This is most clearly illustrated in the organic-rich sediments at Site 680 . Between 0.3 and 22 mbsf, the proportion of total sulfur held in kerogen increases from $20 \%$ to $46 \%$, despite a slight decrease in TOC. Such high proportions of organically bound sulfur are similar to those found in sediments from the Monterey Formation, again indicating the crucial influence of early diagenetic reactions on the sulfur geochemistry of deeply buried sediments.

\section{SUMMARY AND CONCLUSIONS}

Measurements of pore-water sulfide and solid-phase sulfur species show the following:

1. Pore-water sulfide defines classic "bell-shaped" profiles. Maximum concentrations are 6 to $12 \mathrm{mM}$.

2. More than $95 \%$ of the total sedimentary sulfur (TSS) is held in pyrite and kerogen. Up to $45 \%$ of the TSS is organically bound, a much greater proportion than in nearshore, terrigenous muds.

3. Pyrite forms mainly in the top meter or two of the sediment column; a deeper maximum of AVS implies continued, slow reaction of sulfide with iron to a depth of between 20 and $50 \mathrm{mbsf}$.

4. Incorporation of reduced sulfur into organic matter occurs over the top $15 \mathrm{~m}$ of the sediments at both sites. Sulfur contents of $12 \mathrm{wt} \%$ are reached in kerogen at both sites, like those measured in lithologically similar, but more deeply buried, sediments from the Monterey Formation (Orr, 1986). Early diagenetic reactions appear to exert a major influence on the sulfur content of kerogen, and thus of crude oil.

5. Maximum concentrations of elemental sulfur occur in surface sediments, probably as a result of sulfide oxidation.

6. We speculate that an apparent loss of sulfur from organic matter in deep Site 686 sediments may be mediated by fermentative bacteria.

7. The saline brine has only a minor influence on the geochemistry of solid-phase sulfur in Site 680 sediments.

\section{ACKNOWLEDGMENTS}

We thank the Leg 112 shipboard scientists, especially Miriam Kastner and Geoff Eglinton, for collecting samples for us, and BP for permission to publish. The reviews of M. Goldhaber, E. Suess, and an anonymous reviewer improved the original manuscript. This work was performed with the help of Natural Environment Research Council award GST/02/249.

\section{REFERENCES}

Berner, R. A., 1964. An idealized model of dissolved sulfate distribution in recent sediments. Geochim. Cosmochim. Acta, 28:14971503.

1970. Sedimentary pyrite formation. Am. J. Sci., 268:1-23. Berner, R. A., and Westrich, J. T., 1985. Bioturbation and the early diagenesis of carbon and sulfur. Am. J. Sci., 285:193-206.

Canfield, D. E., Raiswell, R., Westrich, J. T., Reaves C. M., and Berner, R. A., 1986. The use of chromium reduction in the analysis of reduced inorganic sulfur in sediments and shales. Chem. Geol., 54:149-155.

Chanton, J. P., and Martens, C. S., 1985. The effects of heat and stannous chloride on the active distillation of acid volatile sulfide 
from pyrite-rich marine sediment samples. Biogeochemistry, $1: 375-383$.

Chanton, J. P., Martens, C. S., and Goldhaber, M. B., 1987. Biogeochemical cycling in an organic-rich coastal marine basin. 7 . Sulfur mass balance, oxygen uptake and sulfide retention. Geochim. Cosmochim. Acta, 51:1187-1199.

François, R., 1987. A study of sulfur enrichment in the humic fraction of marine sediments during early diagenesis. Geochim. Cosmochim. Acta, 51:17-27.

Gallardo, V. A., 1977. Large benthic microbial communities in sulfide biota under Peru-Chile subsurface countercurrent. Nature, 268:331-332.

Goldhaber, M. B., Aller, R. C., Cochran, J. K., Rosenfeld, J. K., Martens, C. S., and Berner, R. A., 1977. Sulfate reduction, diffusion, and bioturbation in Long Island Sound sediments: report of the FOAM group. Am. J. Sci., 277:193-237.

Goldhaber, M. B., and Kaplan, I. R., 1980. Mechanisms of sulfur incorporation and isotope fractionation during early diagenesis in sediments of the Gulf of California. Mar. Chem., 9:95-143.

Gransch, J. A., and Posthuma, J., 1974. On the origin of sulfur in crudes. Adv. in Geochem., 1973:727-739.

Jorgensen, B. B., 1977. The sulfur cycle of a coastal marine sediment (Limfjorden, Denmark). Limnol. Oceanogr., 22:814-832.
1988. Ecology of the sulfur cycle : oxidative pathways in sediments. In Cole, J. A., and Ferguson, S. J. (Eds.), The Nitrogen and Sulfur Cycles. Soc. Gen. Microbiol. Symp. 42:31-63.

Kaplan, I. R., Emery, K. O., and Rittenberg, S. C., 1963. The distribution and isotopic abundance of sulfur in recent marine sediments off southern California. Geochim. Cosmochim. Acta, 27:297-331.

Orr, W. L., 1986. Kerogen/asphaltene/sulfur relationships in sulfurrich Monterey oils. Adv. Org. Geochem., 10:499-516.

Raiswell, R., Buckley, F., Berner, R. A., and Anderson, T. F., 1988. Degree of pyritization of iron as a paleoenvironmental indicator of bottom-water oxygenation. J. Sediment. Petrol., 58:812-819.

Rickard, D. T., 1975. Kinetics and mechanism of pyrite formation at low temperatures. Am. J. Sci., 274:636-652.

Suess, E., von Huene, R., et al., 1988. Proc. ODP, Init. Repts., 112: College Station, TX (Ocean Drilling Program).

Westrich, J. T., 1983. The consequences and controls of bacterial sulfate reduction in marine sediments [Ph.D. dissert.]. Yale Univ., New Haven.

Date of initial receipt: 8 August 1988

Date of acceptance: 5 July 1989

Ms 112B-192 